\section{Akimov O., Penzev P., Marynenko D., Saltykov L.}

\title{
IDENTIFICATION OF THE BEHAVIOR OF PROPERTIES OF A COLD-HARDENING GLA5S-LIOUID MIXTURE WITH PROPYLENE-CARBONATE DIFFERENT IN DOSING COMPONENTS
}

Об'єктом дослідження є моделі, що описують вплив рідкого скла та пропіленкарбонату як затверджувача формувальної суміші на ї властивості. Одним з найбільш проблемних місцьє визначення поведінки властивостей суміші за умов відхилення від оптимальних значень вмісту рікого скла як зв'язуючого та пропіленкарбонату як затверджувача. Визначення такої поведінки важливо через те, що дозволить вдосконалювати процеси регулювання завантаження змішувачів в автоматизованих системах виготовлення суміші в ливарних цехах.

В ході дослідження використовувалися методи канонічного перетворення поверхней відгуку, що описують вплив вмісту рідкого скла та пропіленкарбонату на наступні властивості суміші: живучість, межа міцності на стиск через 1 годину, через 3 години, через 24 години, осипаємість. Описано механізми хімічних реакиій, що приводять до процесу затвердження суміші та через визначення хімізму процесу обтрунтовано можливість отримання якісних характеристик суміші.

Отримано у канонічному вигляді аналітичний опис поверхні відгуку в стаціонарній області у перетвореному за стандартною процедурою факторному просторі «вміст рідкого скла - вміст пропіленкарбонату». Таке перетворення дозволяє оцінити характер поверхні відгуку через аналіз співвідношень власних чисел, що входять до ї канонічного опису, за величиною та знаком. Такий використаний підхід має важливу особливість, так як дозволяє безпосередньо визначити поведінку властивостей суміші в разі відхилення від оптимальних значень вмісту рідкого скла та пропіленкарбонату.

Завдяки цьому забезпечується можливість визначення заходів або технічних рішень щодо роботи або вдосконалення систем регулювання процесів дозування в автоматизованих системах виготовлення суміші в ливарних цехах. При цьому можлива адаптація до будь-яких відомих систем дозування зв'язуючих та затверджувачів холоднотвердіючих сумішей. Це відкриває перспективи щодо стабілізації якості формувальної чи стрижньової суміші та підвищення якості фасонних виливків для машинобудування, зокрема відповідальних та базових литих деталей двигунів внутрішнього згоряння (ДВЗ).

ключові слова: холоднотвердіюча суміш, пропіленкарбонат, рідке скло, властивості суміші, дозування компонентів, канонічне перетворення поверхні відгуку.

\section{Introduction}

Improving the quality of molding compounds is a prerequisite for obtaining high-quality castings for engineering purposes. If the castings are responsible and they are presented with improved properties of geometric and dimensional accuracy, for example, cast parts of internal combustion engines (ICE), then the quality control of molding sands (MS) is of particular relevance. High quality MS is also one of the resource saving factors, as it allows to obtain a cleaner surface of the castings, reducing the amount of allowances for machining. Therefore, the chemical industry specializing in the synthesis of MS components for the foundry industry faces the task of finding the best solutions for the component composition of the MS in terms of the use of binders and catalysts. In this direction, active developments are underway, among which [1,2], for example, can be noted, in which the effect of hardeners on MS properties, in particular their regenerable abilities, has been investigated. Improving the MS properties is considered through the use of new solutions in the field of chemical technologies, as exemplified by the results of the study of the effect of furfuryloxypropylcyclocarbonates (FOTPCC) for cold hardening mixtures (CHM) [3]. However, such new solutions in the field of chemical synthesis often require the use of new special technological equipment. In the conditions of limited capacities of enterprises for the modernization of production, it is important to search for solutions that are aimed at combining the possibilities of automating technological processes of mixing and searching for optimal MS compositions that can be used in such automated systems. One example of such an implementation can be a dosing system for the main available components of the CHM, for example, liquid glass and propylene carbonate. In this case, of interest is the study of the question of possible changes in the properties of mixtures with deviations from the optimum amount of liquid glass and propylene carbonate. Appropriate adjustments can be taken into account in the dosing systems used in the processes and systems of mixing. 


\section{The object of research and its technological audit}

The object of research is models that describe the effect of liquid glass and propylene carbonate as a hardener of the molding mixture on its properties. Namely: survivability, compressive strength after 24 hours, crumbling after 24 hours of hardening. The validity of the choice of object is related to the fact that the studied components of the mixture find a great practical application in those conditions when the transition to new technological solutions is difficult. Propylene carbonate is a complex, complete cyclic ester of propylene glycol and carbonic acid with the structural formula:<smiles>CC1COC(=O)O1</smiles>

Propylene carbonate is synthesized in the presence of a catalyst of carbon dioxide and propylene oxide:

$$
\searrow_{\mathrm{O}}^{\mathrm{CH}_{2}}-\mathrm{CH}-\mathrm{CH}_{3}
$$

In the chemical industry, propylene carbonate is used to extract byproducts of gaseous products, for example, $\mathrm{H}_{2} \mathrm{~S}$ in the manufacture of synthetic fibers. Its use in the foundry industry is due to the fact that when it interacts with liquid glass, the ester is hydrolyzed in an alkaline medium to form propylene glycol and carbonic acid. The latter, reacting with liquid glass, causes the formation of silicic acid and sodium bicarbonate. This occurs at the initial stage of hardening. Sodium bicarbonate in the process of further hardening of the mixture reacts with alkali of liquid glass and goes into monohydrate sodium carbonate. The described reactions proceed according to the following scheme:<smiles>COC(NC(=O)[O-])C(C)C1OC(=O)OCC1C</smiles>

$$
\mathrm{Na}_{2} \mathrm{Si}_{2} \mathrm{O}_{5}+\mathrm{H}_{2} \mathrm{CO}_{3} \rightleftarrows \mathrm{Na}_{2} \mathrm{CO}_{3}+\mathrm{H}_{2} \mathrm{Si}_{2} \mathrm{O}_{5}
$$

or

$$
\begin{aligned}
& \mathrm{Na}_{2} \mathrm{O} \cdot \mathrm{nSiO}_{2}+\mathrm{CO}_{2}+\mathrm{mH}_{2} \mathrm{O} \rightleftarrows \\
& \rightleftarrows \mathrm{Na}_{2} \mathrm{CO}_{3}+\mathrm{nSiO}_{2} \cdot \mathrm{mH}_{2} \mathrm{O}
\end{aligned}
$$

At the initial stage of gelation, that is, in the socalled induction period, liquid-glass compositions with propylene carbonate are weakly structured liquids with a slight viscosity gradient. The viscosity of the compositions increases dramatically as the reactions proceed after the end of the induction period. This can be explained by the polycondensation of monomers of silicic acid, formed as a result of the interaction of carbonic acid with liquid glass. Thus, the main product of the interaction of liquid glass with propylene carbonate is silicic acid $\mathrm{Si}(\mathrm{OH})_{4}$, which forms a high degree of polycondensation silica polymer, which is responsible for forming the strength of the foundry molding sands. Identification of the strength of the mixture and its other technological parameters when using various combinations in the content of liquid glass and propylene carbonate is the task of technological audit. Experimental data obtained in the course of research can be used to build mathematical models and find optimal solutions for the choice of the composition of molding compounds that satisfies one priority or several specified properties.

\section{The aim and objectives of research}

The aim of research is the analysis of response surfaces, describing the influence of the composition of cold-hardening mixtures on their properties, in a stationary region.

To achieve this aim it is necessary to:

1. Determine the nature of the stationary regions depending on the properties of the mixtures based on the canonical transformation of the response surface for each of the investigated parameters.

2. Evaluate possible changes in the properties of mixtures with deviations in the dosing of liquid glass and propylene carbonate.

\section{Research of existing solutions of the problem}

In [4], a method for obtaining an optimal solution for reducing the amount of liquid glass in a mixture while maintaining acceptable strength for raw material is shown using a ridge analysis. The results are shown on the example of using propylene carbonate as a hardener. However, as the output variable, only the compressive strength of the molding sand is used.

In [5], an optimization problem is solved to determine the CHM composition based on liquid glass and propylene carbonate as a binder and hardener, respectively, with the choice of the optimization criterion for the maximum survivability of the mixture and the minimum of crumbling. It is noted that the obtained results can be used in the automated production of molding sand to improve the quality of cast parts of the internal combustion engine.

The mathematical model described in [6] makes it possible to establish that the priority factor influencing the strength of a sample subjected to thermal drying with magnetized liquid glass is the magnetic field strength. The paper presents the optimal technological parameters of the process, however, this model can't be applied to optimize the CHM components with propylene carbonate.

In [7], a regression equation is obtained reflecting the functional relationship between such properties of a mixture with liquid glass and a hardener - survivability, compressive strength, and crumbling. The authors of this work have shown that compressive strength is a more significant factor influencing the survivability compared with crumbling, and almost 3 times. It ws also concluded that both of these factors have a positive effect on the survivability of the mixture - with an increase in compressive 
strength and crumbling stability, vitality increases. However, issues related to the influence of deviations from the given values of the content of the binder and hardener is not investigated. A partial answer to this question in this paper can be found by analyzing the ridge lines, however such accents in [7] are not made.

A complex of mathematical models describing the influence of the content of liquid glass and propylene carbonate in the CHM is given in [8], in which the problem of the optimal combination of the properties of the synthesis of the CHM composition is also solved. The given rational regions of the compositions allow in some way to remove the restriction indicated in [7]; however, a more rigorous analysis of the stationary regions for each of the properties under study would allow obtaining more accurate results. In particular, it would be of interest to study the behavior of properties with deviations from the optimal values of the content of the binder and hardener. The obtained results could find practical application in automated processes for mixing and creating more advanced dosing controls for mixing preparation systems. Relevant technical solutions may be of interest to world manufacturers specializing in the manufacture of mixing preparation equipment, such as:

- Belloi \& Romagnoli S.r.l. (Italy) [9];

- Webac Maschinenbau GmbH (Germany) [10];

- DISA Group (a large international company with branches worldwide) [11].

\section{Methods of research}

Mathematical models obtained by the method of planning an experiment based on the construction of a central orthogonal design of a full factorial experiment are analyzed [8, 12, 13]:

$$
\begin{aligned}
& a_{i}=c_{1} \sum_{j=1}^{N} x^{j} y^{j}, i=1, \ldots, n, \\
& a_{i}=c_{2}\left[\left(x_{i-n}^{j}\right)^{2}-\beta\right] y^{j}, i=n+1, \ldots, 2 n, \\
& a_{i}=c_{3} \sum_{j=1}^{N} x_{\mu}^{j} x_{\lambda}^{j} y^{j}, i=1, \ldots, n, \mu \neq \lambda, i=2 n+1, \ldots, k, \\
& a_{0}=\frac{1}{N} \sum_{j=1}^{N} y^{j}-\beta \sum_{j=1}^{N} a_{n+i} .
\end{aligned}
$$

In formulas (1)-(4): $c_{1}, c_{2}, c_{3}$ - coefficients for linear, quadratic and paired relationships, respectively; $n-$ the number of linear terms of the equation; $N$ - the number of experiments; $\beta$ - parameter calculated depending on the number of points of the core of the composition plan $2^{n-p}$, the leg of the «star» points $\alpha$ and the number of points to the plan according to the formula:

$$
\beta=\frac{\sum_{j=1}^{N}\left(x_{i}^{j}\right)^{2}}{N}=\frac{2^{n-p}+\alpha}{N} .
$$

To analyze the stationary region and describe the behavior of the output variables - CHM properties using liquid glass as a binder and the curing agent of propylene carbonate - the canonical transformation of the response surface is performed [14]. The conversion is carried out according to the procedure below.

1. Determination of the coordinates of the stationary point $x^{*}$ by solving a system of linear equations:

$$
\left(\begin{array}{ccc}
a_{11} & \ldots & a_{1 n} \\
\vdots & \ddots & \vdots \\
a_{m 1} & \cdots & a_{m n}
\end{array}\right)\left(\begin{array}{c}
x_{1}^{*} \\
\ldots \\
x_{n}^{*}
\end{array}\right)=-\left(\begin{array}{c}
a_{1} \\
\ldots \\
a_{n}
\end{array}\right)
$$

2. Calculation of the target value at the stationary point:

$$
y^{*}=a_{0}+2 a^{\prime} x^{*}+x^{* \prime} A x^{*} .
$$

3. Determination of $n$ eigenvalues $\lambda_{1}, \lambda_{2}, \ldots, \lambda_{n}$ :

$$
\left|\begin{array}{cccc}
a_{11}-\lambda & a_{12} & \ldots & a_{1 n} \\
a_{21} & a_{22}-\lambda & \ldots & a_{2 n} \\
\cdot & \cdot & . & \cdot \\
a_{n 1} & a_{n 2} & \ldots & a_{n n}-\lambda
\end{array}\right|=(-\lambda)^{n}+P_{1} \lambda^{n-1}+\ldots P_{n}=0
$$

4. Notation of the response surface equation in canonical form:

$$
y-y^{*}=\lambda_{1} \xi_{1}^{2}+\lambda_{2} \xi_{2}^{2}+\ldots+\lambda_{n} \xi_{n}^{2}
$$

Thus, as a result of the transfer and rotation of the axes and the transition from the coordinate system $\left(x_{1} ; x_{2}\right)$ to the coordinate system $\left(\xi_{1} ; \xi_{2}\right)$, the initial equation for the response surface is transformed:

$$
y(x)=a_{0}+2 a^{\prime} x+x^{\prime} A x,
$$

to canonical form $y-y^{*}=\lambda_{1} \xi_{1}^{2}+\lambda_{2} \xi_{2}^{2}+\ldots+\lambda_{n} \xi_{n}^{2}$ :

$$
x=x^{*}+B \xi,
$$

where $B$ - rotation matrix; $B^{\prime} B=I$, and the difference between the values of the output variable at an arbitrary and stationary point is described by the equation:

$$
y(\xi)-y^{*}=\xi^{\prime} L \xi
$$

Output variables - the properties of the mixture - are selected:

- mixture survivability, $\min -y_{1}$;

- compressive strength, MPa (after 1 hour) - $y_{2}$;

- compressive strength, MPa (after 3 hours) - $y_{3}$;

- compressive strength, MPa (after 24 hours) $-y_{4}$;

- crumbling, $\%-y_{5}$.

Input variables are:

$-x_{1}-$ content of liquid glass, mass fraction;

$-x_{2}-$ content of propylene carbonate, mass fraction.

\section{Research results}

The following values of the coefficient matrices in equation (7) were obtained to calculate the value of the target quantity at the stationary point: 
- mixture survivability, min:

$a_{0}=14.623, \quad a=\left(\begin{array}{l}0.208 \\ 0.083\end{array}\right)$,

$A=\left(\begin{array}{cc}0.0325 & 0 \\ 0 & -0.2175\end{array}\right)$

- compressive strength, MPa (after 1 hour):

$a_{0}=1.166, \quad a=\left(\begin{array}{c}-0.094 \\ 0.151\end{array}\right)$

$A=\left(\begin{array}{cc}0.068 & 0.0325 \\ 0.0325 & -0.112\end{array}\right)$

- compressive strength, MPa (after 3 hours);

$a_{0}=2.388, \quad a=\left(\begin{array}{c}-0.083 \\ 0.213\end{array}\right)$

$A=\left(\begin{array}{cc}0.1534 & 0.125 \\ 0.125 & -0.242\end{array}\right)$

- compressive strength, MPa (after 24 hours):

$a_{0}=5.284, \quad a=\left(\begin{array}{c}0.535 \\ -0.13\end{array}\right)$

$A=\left(\begin{array}{cc}-0.207 & 0.0275 \\ 0.0275 & -0.327\end{array}\right)$

- crumbling, \%:

$a_{0}=0.068, \quad a=\left(\begin{array}{c}-0.035 \\ 0.010\end{array}\right)$

$A=\left(\begin{array}{cc}0.045 & -0.014 \\ -0.014 & 0.015\end{array}\right)$

The implementation of procedure 1-4 yields the following results in the form of equations describing the response surface in canonical form:

- for the mixture survivability:

$y-y^{*}=-0.2175 \xi_{1}^{2}+0.0325 \xi_{2}^{2}$

- for the compressive strength, MPa (after 1 hour):

$y-y^{*}=-0.1178 \xi_{1}^{2}+0.0736 \xi_{2}^{2}$

- for the compressive strength, MPa (after 3 hours):

$y-y^{*}=-0.2778 \xi_{1}^{2}+0.1896 \xi_{2}^{2}$

- for the compressive strength, MPa (after 24 hours):

$y-y^{*}=-0.3333 \xi_{1}^{2}+0.2013 \xi_{2}^{2}$
- for the crumbling, \%:

$$
y-y^{*}=0.0097 \xi_{1}^{2}+0.0504 \xi_{2}^{2} .
$$

To determine the type of stationary region, it is possible to analyze the ratios of the eigenvalues. In terms of size and sign, they will determine the type of response surface and the type of the corresponding two-dimensional sections of the response surface ( 4 variants of two-dimensional sections are given below):

- option 1 - hyperbola (stationary point - ridge point):

$\left|\lambda_{1}\right| \neq\left|\lambda_{2}\right|, \lambda_{1}<0, \lambda_{2}>0$

- option 2 - hyperbola (stationary point - ridge point):

$\left|\lambda_{1}\right| \neq\left|\lambda_{2}\right|, \lambda_{1}>0, \lambda_{2}<0$

- option 3 - ellipses (stationary point - maximum):

$\left|\lambda_{1}\right| \neq\left|\lambda_{2}\right|, \lambda_{1}<0, \lambda_{2}<0$

- option 4 - ellipses (stationary point - minimum):

$\left|\lambda_{1}\right| \neq\left|\lambda_{2}\right|, \lambda_{1}>0, \lambda_{2}>0$.

Analysis of the equation describing the stationary region for survivability (11) suggests that there are hyperbolas in the two-dimensional section. Deviation in the dosing of propylene carbonate in a large direction with accurate dosing of liquid glass will lead to a distance from the stationary point. However, based on the fact that the stationary region has a ridge point, and it is necessary to maximize survivability, such a deviation is not critical. The question of the magnitude of the deviations of the values of survivability from the local maximum in the case of inaccuracy of dosing of propylene carbonate relative to its locally optimal value can be solved by analyzing ridge lines [5]. These locally optimal values correspond to the points of intersection of the response surface and the surface of the restrictions imposed by the planning area of the experiment.

Analysis of equations (12)-(14), describing the stationary region for the ultimate strength of the mixture, regardless of the control time, suggests that all conclusions made regarding survivability are also valid in relation to the strength of the mixture.

Other conclusions can be made with respect to the stationary region described by equation (15) for crumbling. Deviations in dosing in a large way and for propylene carbonate, and for liquid glass leads to the removal of the crumbling value from the optimal value. Since the optimum point is a minimum point (option 4), this option is unacceptable. The deviation in the dosing of propylene carbonate and liquid glass downwards also causes the crumbling value to deviate from the optimum, but in the other direction.

The obtained solutions can be used as an element of decision support systems, and the technical implementation of the obtained results assumes the use of mixture preparation in automated systems. A fragment of such a general scheme at the level of the conditional representation of the dosing circuits of the components may have the form shown in Fig. 1. 


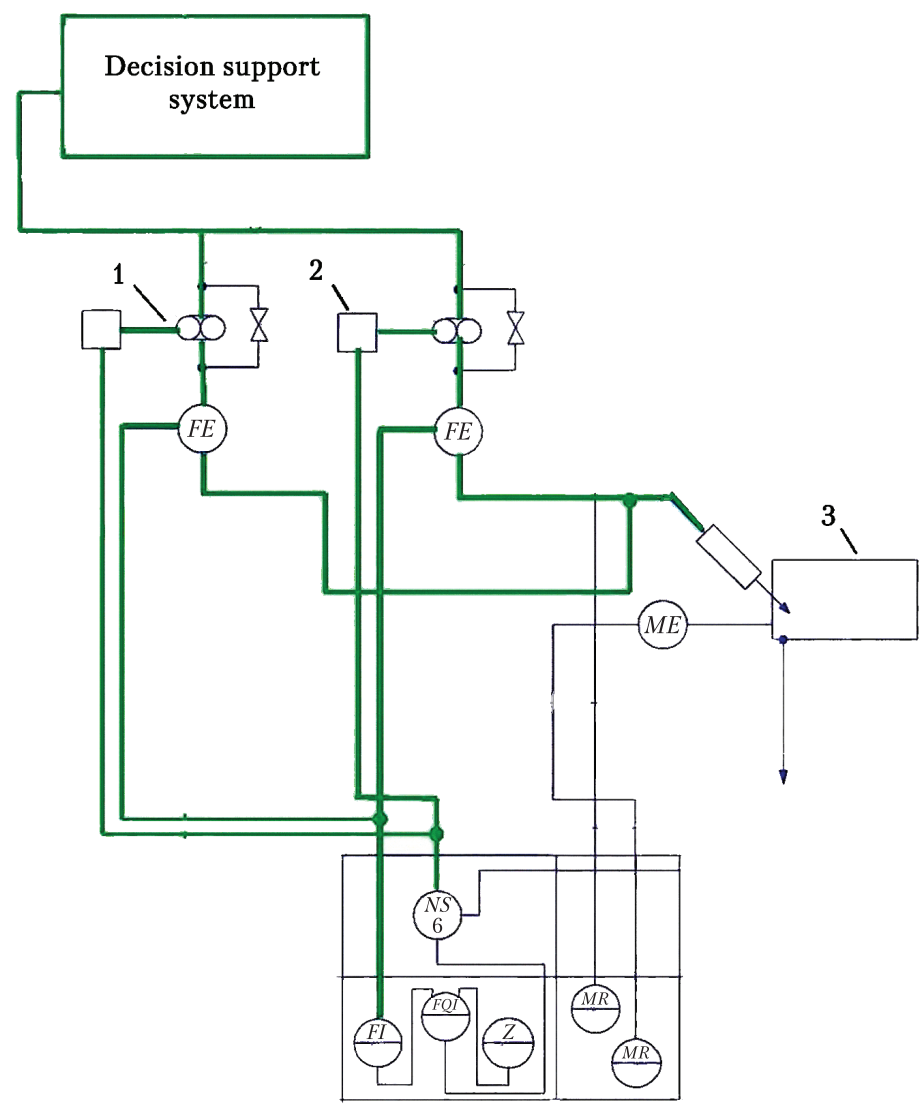

Fig. 1. Conditional functional diagram of the dosing of liquid glass and propylene carbonate: 1 - dosing circuit of liquid glass; 2 - dosing circuit of propylene carbonate; 3 - mixer associated with the need for technical implementation.

In particular, the resulting mathematical descriptions should be part of decision support systems for automated dosing systems in the mixing process.

Opportunities. Opportunities when using the above results in industrial conditions are associated with the stabilization of the quality of the mixture and the resulting molded parts obtained with its use. In addition, it is possible to talk about improving the accuracy of dosing of liquid glass and propylene carbonate, focusing on maintaining the optimal amount of binder and hardener.

Threats. Obvious threats when using the obtained results are related to the fact that the existing solutions in the field of automation of technological processes of mixing preparation are focused on the use of their mathematical description, which is part of the software and hardware. In addition, there are a large number of new technological processes and modern mixtures, using other components. The combination of modern solutions in the field of mixtures and process equipment eliminates the possibility of widespread use of the solutions obtained in this research.

The obtained results can be used only where there are grounds for this, for example, using liquid glass as a binder and propylene carbonate as a hardener. Attempting to implement in other conditions may not meet expectations and may be among the risks.

\section{SWOT analysis of research results}

Strengths. The strength of this research is obtaining an analytical description of the behavior of the properties of a cold-hardening mixture with deviations from the optimal values of the binder amount - liquid glass and the hardener - propylene carbonate. Due to its canonical appearance, the obtained description provides an opportunity to see how, for example, it will affect the studied properties of the mixture - survivability, ultimate compressive strength and crumbling - fluctuations in the number of loaded components. The latter may be caused by inaccuracy of their dosing. On the one hand, it is obvious that the costs of implementing the process of mixing preparation are directly related to the consumption of components. Therefore, consumption in a big way leads to their overspending. On the other hand, deviations from the optimal values of the number of components lead to an increase in the probability of a decrease in the quality of the mixture. This can lead to casting defects for reasons of violation of geometric and dimensional accuracy and surface quality. If the cast parts are the critical parts of an internal combustion engine, this is especially problematic. Therefore, the solutions obtained allow to quickly prevent these problems, minimizing the cost of the process and reducing the likelihood of lowquality casting.

Weaknesses. The weak points of this research are related to the fact that the practical application of the obtained theoretical solutions implies additional costs

\section{Conclusions}

1. On the basis of the canonical transformation of the obtained response surface, a different character of stationary regions is revealed, depending on the properties of the mixtures. So, the presence of a ridge point is revealed for survivability and compressive strength. This means that a change in the dosing of propylene carbonate will cause an offset from this point, but it is not critical, since the magnitude of vitality must be maximized. The absolute change in the position of the maximum in this case can be estimated on the basis of the analysis of the ridge lines describing the locally optimal values as the intersection points of the response surface and the surface of the restrictions imposed by the planning area of the experiment.

2. It is shown that the deviation in the dosing of propylene carbonate and liquid glass leads to the removal of the value of crumbling from the optimal value. Since the optimum point is a minimum point, this option is unacceptable. Therefore, the issue of dosing accuracy in terms of minimizing flaking is particularly important.

\section{Acknowledgments}

The authors' team is grateful to the Associate Professor of the Foundry Department of the National Technical University «Kharkiv Polytechnic Institute» (Ukraine) B. Kovalenko for consulting assistance in describing the curing mechanism and explaining the chemistry of this process. 


\section{References}

1. Evtushenko N. S., Shinskii O. I., Ponomarenko O. I. Issledovanie svoistv regeneriruemykh smesei na osnove OFOS // Kompressornoe i energeticheskoe mashinostroenie. 2013. Issue 4. P. $48-51$.

2. Ponomarenko O. I., Evtushenko N. S., Berlizeva T. V. Vliianie zhidkikh otverditelei s raznymi dobavkami na svoistva zhidkostekolnykh smesei // Liteinoe proizvodstvo. 2011. Issue 4. P. 21-24.

3. Vliianie furfuriloksipropilciklokarbonatov (FOPCK) s razlichnymi dobavkami na svoistva kholodnotverdeiushchikh smesei na zhidkom stekle / Berlizeva T. V., Ponomarenko O. I., Karateev A. M., Litvinov D. A. // Kompressornoe i energeticheskoe mashinostroenie. 2013. Issue 3. P. 26-29.

4. Application of liquid glass mixtures with reduced content of liquide glass as a factor in improving the quality of machine-building castings / Zinchenko P. S., Aksenenko M. P., Iovbak A. V., Orendarchuk Iu. V. // ScienceRise. 2016. Vol. 5, Issue 2 (22). P. 6-9. doi: http://doi.org/10.15587/2313-8416.2016.69836

5. Optimizaciia skladu formuvalnikh sumishei dlia avtomatizovanogo virobnictva litikh detalei dviguniv vnutrishnogo zgoriannia / Orendarchuk Iu. V., Krasnoukhova A. A., Achkasov I. O., Barsuk A. S., Golovko V. I. // Visnik NTU «KHPI». 2016. Issue 50 (1222). P. 117-121.

6. Optimization of thermal drying of liquid glass mixture according to tensile strength criterion / Zinchenko P. S., Golinkov V. V., Starykh S. A., Stupar M. A. // ScienceRise. 2016. Vol. 6, Issue 2 (23). P. 9-13. doi: http://doi.org/10.15587/23138416.2016 .69970

7. Obtaining of locally optimal solutions by combining properties of mixtures for foundry manufacture / Dotsenko V., Boichuk V., Fedorenko V., Tsybulskyi Y. // EUREKA: Physics and Engineering. 2018. Vol. 6. P. 48-53. doi: http://doi.org/ 10.21303/2461-4262.2018.00795

8. Kovalenko B. P., Demin D. A., Bozhko A. B. Optimizaciia sostava kholodnotverdeiushchikh smesei (KHTS) s propilenkarbonatom // Eastern-European Journal of Enterprise Technologies. 2006. Issue 6. P. 59-61.
9. INTENSIVE MIXER. URL: http://www.belloi.it/

10. Durchlaufmischer. URL: https://www.webac-gmbh.de/produkte/ uebersicht/

11. DISA. Mixers and SMC. URL: https://www.disagroup.com/ en-gb/products/sand-preparation-and-cooling/mixers-and-smc

12. Hartmann K., Lezki E., Schafer V. Planirovanie eksperimenta $\mathrm{v}$ issledovanii tekhnologicheskikh processov. Moscow: Mir, 1977. $552 \mathrm{p}$

13. Demin D. Synthesis of optimal control of technological processes based on a multialternative parametric description of the final state // Eastern-European Journal of Enterprise Technologies. 2017. Vol. 3, Issue 4 (87). P. 51-63. doi: http://doi.org/ 10.15587/1729-4061.2017.105294

14. Demin D. Strength analysis of lamellar graphite cast iron in the «carbon $(\mathrm{C})$ - carbon equivalent $(\mathrm{Ceq})$ » factor space in the range of $\mathrm{C}=(3.425-3.563) \%$ and $\mathrm{Ceq}=(4.214-4.372) \% / /$ Technology Audit and Production Reserves. 2017. Vol. 1, Issue 1 (33). P. 24-32. doi: http://doi.org/10.15587/2312-8372.2017.93178

Akimov Oleg, Doctor of Technical Sciences, Professor, Head of Department of Foundry, National Technical University «Kharkiv Polytechnic Institute», Ukraine, ORCID: http://orcid.org/00000001-7583-9976,e-mail: litvo11@kpi.kharkov.ua

Penzev Pavel, Assistant, Department of Foundry, National Technical University «Kharkiv Polytechnic Institute», Ukraine, ORCID: http:// orcid.org/0000-0002-6771-4169, e-mail: litvo11@kpi.kharkov.ua

Marynenko Dmytro, Postgraduate Student, Department of Foundry, National Technical University «Kharkiv Polytechnic Institute», Ukraine, ORCID: http://orcid.org/0000-0003-3252-9649, e-mail: litvo11@kpi.kharkov.ua

Saltykov Leonid, Postgraduate Student, Department of Foundry, National Technical University «Kharkiv Polytechnic Institute», Ukraine, ORCID: http://orcid.org/0000-0003-2640-8074, e-mail: litvo11@kpi.kharkov.ua 